\title{
Exploring the Concept of Equal Opportunity in Teaching and Learning of Geography in Selected Secondary Schools of Kabwe District, Zambia
}

\author{
Kasonde Mundende $^{1^{*}}$, Professor Charles M Namafe ${ }^{2}$ \\ ${ }^{1}$ Institute of Distance Education, University of Zambia, Box 32379, Lusaka \\ ${ }^{2}$ School of Education, the University of Zambia, P.O. Box 32379, Lusaka, Zambia
}

*Corresponding Author: Kasonde Mundende, Institute of Distance Education, University of Zambia, Box 32379, Lusaka

\begin{abstract}
This study focused on enhancing performance in geography at the School Certificate level, where 'equal opportunity' for teaching and learning must be provided to all learners. In this study, 'equal opportunity' was taken to be the provision of educational opportunities to all learners without any form of discrimination to enhance performance. For some time now, performance in geography at the School Certificate level in Zambian Secondary Schools has been at the level of under-achievement. From 2010 to 2017, only about 20\% of learners in Kabwe District Secondary Schools scored Grades 1 to 4 (DistinctionMerit), while the rest of learners, earned Grades 5 to 9 (Credit-Fail). In this study, earning grades above 4 was considered under-achievement. The purpose of this study was to explore the extent to which the concept, 'equal opportunity' was conducted in the teaching and learning of geography. A qualitative approach and a descriptive research design were implored. Two hundred and one (201) key stakeholders participated in the study. The main finding indicated that under-achievement in geography was a result of lack of in-depth individualised learner attention and the main recommendation is that the Ministry of General Education should vigorously implement performance-related learning and teaching practices in schools.
\end{abstract}

Keywords: Equal opportunity, Education, Under-achievement, performance, Geography.

\section{BACKGRound To The STUdY}

The premise of this study is that to improve and enhance performance in geography at the School Certificate level, 'equal opportunity' for teaching and learning must be provided to all learners of geography. 'Equal opportunity' implies earning educational attainment at its highest level, where no learner is left behind or denied the opportunity to excel. Pop (2012), in reference to the public education system in Albania, Bulgaria, Czech Republic, Estonia, Hungary, Ireland, Mongolia, Montenegro, Nepal, Turkey, and the United Kingdom, lamented that there was no public education system in the world that was completely free of unequal educational opportunities. Individuals continue advocating for interventions against 'unequal opportunities', but there have been no standards or agreed-upon ways to address 'unequal opportunities' that have been forthcoming (Pop, 2012; Burbules et al., 1982). Okada (2012: 27) stressing the importance of education as a universal human right, stated that,
"We insist that education is a social and universal human right. Irrespective of rich and poor, all people in this civilized world have a right equally to receive education. It is a boon of civilized society and a public good of human society. Nobody should monopolize it as their private property. Therefore, the state should have a duty to establish public schools and bear the expense of providing them to the people."

Zambian Government observed that 'unequal opportunities' existed in education and other sectors of development. In this regard, the World Bank (2018) attributed the poor academic performance in Zambia to the low quality of education, increased student enrollment, teacher quality and supply, inadequate teaching and learning materials, and school governance. By poor/low teacher quality implies, some learners were taught by diploma holders who according to the Zambian Educational policy, "Educating our Future", did not qualify to teach senior grades (MoE, 1996). In relation to 
school governance, there was little monitoring and evaluating of what individual teachers were doing on daily basis. The Zambian Ministry of Education (MoE) (2012) lamented that the unsatisfactory levels of learning achievement in Zambia, had been at variance with intervention measures the Ministry had been putting in place such as provision of school infrastructure, furniture and recruitment of teachers.

The subject of Geography has not been an exception in the unsatisfactory performance 'tag' because from 2010 - 2017, about $80 \%$ of learners in geography had consistently performed poorly at School Certificate level, "except for 2013 where the mean raw mark was 46.76 compared to 41.18 in 2012 "(ECZ, 2013: 25). Teaching is defined as enabling learning to take place so that learners make good progress and show good attitudes to their work (Watkinson, 2010). In this study, teaching means ensuring that learners are equipped with knowledge, skills and attitudes in geographical concepts in order to enhance their performance. Guy (2009) defined learning as an experience which produces a stable change in someone's knowledge or behaviour. Under-achievement in this study refers to academic performance by Zambian candidates who sat for geography and scored the grades of 5 to 9 as opposed to those who earned grades of 1 to 4 . Scores 5 to 9 were considered under-achievement because they contributed to the candidates' overall poor or low performance at the District, Provincial and National levels, thus, affecting the candidate's individual performance. According to Mayhew (2015: 208), geography is "the science of place and space. The subject that bridges the natural and human sciences in understanding societies, places and environments."

\section{Statement of the Problem}

A global concern of 'unequal opportunities' in the provision of education affects the Zambian Education System too. In Zambia, from 2010 to 2017, less than $20 \%$ of geography School Certificate learners scored highly, whilst about $80 \%$ scored poorly which, in this study is operationalised as under-achievement. The general question of interest to this study was, 'What contribution if any, did 'unequal opportunity' make towards such under-achievement in Zambian Secondary School geography?" This question has never been asked before through a systematic study and deserves to be explored for several reasons. First, the question deserves an answer so that a solution to underachievement can be found. Second, the concept of 'equal opportunity' should be explored to check on the extent it has been a major contributor to under-achievement in geography. Consistent underachievement would make learners to lose interest in the discipline, making it difficult to recruit future geographers. Does 'equal opportunity' exist in Kabwe District of education? Does it exist anywhere? Since we do not know the answers to these concerns, is deemed important to investigate the phenomenon of 'equal opportunity' in the Zambian geography school certificate teaching and learning.

\subsection{Purpose of the Study}

To explore the concept of 'equal opportunity' in the teaching and learning of geography in Zambian Senior Secondary Schools of Kabwe District.

\subsection{Objective of the Study}

To identify causes of under-achievement in the teaching and learning of geography that may relate to 'equal opportunity' in Zambian Senior Secondary Schools of Kabwe District.

\subsection{Research Question}

What caused under-achievement in the teaching and learning of geography that may relate to 'equal opportunity' in Zambian Senior Secondary Schools of Kabwe District?

\subsection{Significance of the Study}

Because the performance in geography at the school certificate level continues to be low, it is hoped that the findings of this study may: (1)equip the Ministry of General Education with appropriate information in the teaching and learning of geography which may lead to high achievement at school certificate level; (2) contribute to the general body of knowledge on the teaching and learning of geography to promote 'equal opportunity'; (3) equip the researcher, as a teacher trainer, with relevant skills, knowledge, attitude and information, to prepare trainee teachers with relevant information on what they were expected to do concerning provision of 'equal opportunities' when they finally qualify 
as teachers and; (4) equip the geography stakeholders with relevant skills, knowledge and attitudes to meet the demands of the $7^{\text {th }}$ National Development Plan and the Vision 2030 as regards sustainable living.

\section{REVIEW OF RELATED LiTERATURE}

Johari (2012) believed that the rights of all people should be equal and that all should be treated equally before the eyes of the law. He further observed that, since people differed in their needs, capacities, and in their efforts, they needed different opportunities for their individual selfdevelopment. Similarly, Hilda et al., (2014) commended schools which provided 'equal opportunity' to learners with the same qualifications through the same curriculum. Hildaet al., (2014) are criticised by other scholars of creating confusion, because of using similar terms such as 'same' or equal which they claimed provided multiple meanings and interpretations. Due to such multiple meanings, researchers today and in the past have been suggesting dropping the concept of 'equal opportunity' altogether. Nonetheless, Hilda et al., (2014) argued that the concept of 'equal opportunity' should be maintained because what all researchers and scholars agreed upon was the idea of giving each individual same treatment if they were to realise their potential.

From the meritocratic point of view, Okada (2012: 13) views 'equal opportunity' "in terms of equality of access for children to the more advanced stages of education regardless of their sex, social class, religion, ethnic group, or region of origin." From the Conservatists' approach of 'equality of educational opportunity', he argues that God had endowed upon each individual different amounts of capacity, but it was up to individuals to make the best possible utilisation of what had been bestowed upon them (Okada, 2012). By implication, it is assumed that pupils have to make maximum use of their capacity and should be content with it because they had been given what they deserved. Comparatively, Howe and Covell (2013) agree with Okada's (2012) view that political and educational authorities took decision not only to eliminate discrimination but also to level the playing field such that obstacles to opportunities were removed. Contrary to the conservatists, view point, liberalists's understanding of 'equality of opportunity' is that "all pupils should be given the same opportunity to start their life career and not necessarily that it should ultimately bring about greater equality in terms of social and/or economic status" (Okada, 2012: 8). Further, liberalists in their model recognise that there were barriers to success and failure of individuals but they argue that once external barriers were removed, individuals's success or failure would solely depend upon each individual child.

Egalitarianists understand 'equality of equal opportunity' as a person's intelligence was a product of both genetic makeup and their social background to the extent that if the child comes from an environment which is socio-economically disadvantaged, his or her academic work would not be developed because of lack of support from his or her home (Okada, 2012). On the contrary, the NeoMarxist model or approach observed that educational attainment was largely influenced by various resources from the individual's family background and that education in turn, contributed to the social inequality and class structure. The Neo-Marxist theorists accuse schools to be agents of capitalists, which promoted disciplines of working world (Okada, 2012). Comparatively, Howe and Covell (2013) agree with Okada' (2012) view that political and educational authorities took decision not only to eliminate discrimination but also to level the playing field such that obstacles to opportunities were removed.

Woessmann and Peterson (2007: 6) highlight that "opportunities at school might be said to be equal, if all who enter the school house were given the same opportunities to enhance the endowments brought to the school threshold." Therefore, "in the absence of equal representation and participation, unequal outcomes are likely to persist since the terms of success are dictated by dominant groups and located in criteria that best preserve their place in the social hierarchy. Using the above definitions as a basis, the researcher concludes that the concept of 'equal opportunity' is situational and defined differently by different people.

Concerning the causes of underachievement, Pop (2012: 13) stated that in the United States "poverty, physical barriers, financial barriers and linguistic and cultural barriers are the factors that affect the equality of opportunity in education." Similarly, Tilbury and Williams (1997) cite institutional, sociocultural and personal factors as the main factors that affected equal opportunity. Institutional factors 
which impeded the learners' potential to realise their best achievement in geography included long distances which some learners covered from their homes to schools (especially in rural settings), exorbitant fees, and levies paid at school. Socio-cultural hindrances, included the low value placed on education of a girl, the over-burdening of girls with household chores, expectations that girls would automatically find personal fulfillment in child-bearing and male support in marriage, early marriages, and widespread doubt about girls' intellectual abilities.

The Western scenario on socio-cultural hindrances as highlighted by Pop (2012) and Tilbury and Williams (1997) is not different from the Zambian scenario. For instance, The Post (November 2013) carried a story where a Choma (Southern Zambia) District Commissioner (DC) stopped a wedding of two grade nine pupils scheduled for Saturday November 2, 2013 from Chisikili Basic School,

"Hamweemba who looked confused about the development rushed to the school in the company of officers from the district education board secretary where she managed to retrieve one of the girls from the planned marriage.... However, after intensive discussions, the girl agreed to abandon the wedding plans and pursue the education."

World Vision cluster manager for Mumbwa and Kaindu areas of Central Zambia also bemoaned early marriage as a major challenge to education. They noted that,

"One of the biggest challenges to girl child is early marriages. Early marriages deny a girl her childhood, affects her education, and reduces her opportunities. We are seeing an increasing number of girls dropping out of school due to early marriages and pregnancies (The Post, October 13, 2013: 8)."

As regards personal factors, it includes a negative self-image, which the school frequently reinforced and radical socialisation that made one to be passive and submissive (Tilbury and Williams, 1997). Writing about factors influencing poor performance in Science Subjects in some secondary schools of Tanzania (East Africa), Majo (2016) included the absence of incentives and motivation on teachers, lack of teachers, unconducive teaching and learning environments. Other factors he cited were poor teaching and learning materials, poor infrastructure, lack of competent human resource base in science. According to Jensen (2009) poverty contributed to poor academic achievement. He argued that though a proportion of children raised in poverty succeeded, it was evident that many poor learners did not succeed. He further observed that, "children living in poverty tend to spend less time finding out about the world around them and more time struggling to survive within it." (Jensen, 2009: 8). In addition, he lamented that poor children had fewer and supportive networks, fewer cognitive-enrichment opportunities, fewer learning materials, rarely visitlibraries for studying, and were mostly absent from school compared to their more affluent counterparts (Jensen, 2009). Other factors that influenced poor academic performance included socio-economic status of parents. According to Jensen (2009: 11), "Parents who did poorly in school themselves may have a negative attitude about their children's schools and in an effort to protect them, may even discourage their children from participating." Additionally, poor children were more likely than their well - to do children to attend poorly maintained schools with ill-qualified teachers with less-care facilities if they would be available (Jensen, 2009).

Kyriacou (1997: 21) on pupil differences said "the effective teaching lies in the ability of the teacher to set up a learning experience which brings about the desired educational outcomes. It involves "setting up a learning activity for each pupil which is successful in bringing about the type of learning the teacher intends" to achieve (Kryriacou, 1997: 1)

Leat (1997) observed that some pupils were better at geography than others and such difference is attributed to interest, motivation, quality of teaching as well as intellectual development. Concerning failing in geography, Office for Standards in Education (OFSTED) (1995) and Smith (1997) identified geography lessons tasks which were not matched to the differing abilities of pupils as common features why pupils failed geography. Failing revealed weaknesses in the planning of the lessons concerned as well as limitations in the teachers' understanding of pupils learning in geography and of the geographical abilities of their pupils. Therefore, knowing what was appropriate for pupils of different ages and abilities to learn in and through geography was essential if we were to plan for 
and achieve effective progression and differentiation in learning geography (Lambert and Balderstone, 2000). Lambert and Balderstone (2000) commenting on meeting the individual educational needs of a child stated that every child was special and should be treated as such. They further advanced that every child had individual educational needs which should be met and that geography had its own technical language which needed to be mastered if pupils were to progress to higher levels of understanding in geography.

Considering the size of the class as a contributing factor to pupils' performance. Some studies show that smaller classes are easier to manage, teachers know their learners better, and teachers are able to interact more with their learners at social level as compared to what obtains in larger classes (Harfitt, 2015). On the other hand, it may not be always true that teachers of small classes produced marked benefited in their pupils, especially if they did not change their practice of traditional ways of teaching (that is, teacher-centered) (Rice 1999, and Hattle, 2005). In some small sized classes, it was observed that teachers still maintained the same teaching methodology and pedagogy that they employed in regular sized classes, leading to low performance (Harfitt, 2015). Finn and Achilles (1999: 13) "strongly argued that small classes offered powerful teaching opportunities for educators to do more effectively what they know is right in terms of teaching and learning." Comparatively, Finn et al., (2003: 322) advanced that "it is proposed that students become more engaged academically and more engaged socially when class sizes are reduced, and this increased engagement in the classroom is a compelling explanation for increased learning in all subject areas."

\section{Methodology of The Study}

This research adopted qualitative approach to enable authors develop an in-depth understanding of causes of poor academic performance in the teaching and learning of geography for 'equal opportunity' in selected Kabwe District For adopting qualitative approach, the researchers wanted to get stakeholders' beliefs, understanding and ideas of 'equal opportunity' in the teaching and learning of geography in Zambian Senior Secondary Schools. Aryet al., (2010) explained that qualitative approach provided rich descriptive accounts targeted to understanding a phenomenon, a process, or a particular point of view from the perspective of those involved and as for basic interpretative studies, they describe and attempt to interpret experience (Aryet al., 2010). As for the paradigm, the researchers used interpretivist paradigm. According to Rubin et al., (2009) and Willis et al., (2007) interpretivism attempts to develop an in-depth subjective understanding of people's everyday experiences and lives. It seeks deeper meanings and feelings, idiosyncratic reasons for their behaviour.

\subsection{Target Population}

This study purposively selected nine out of twenty schools found in Kabwe District. Four were single sex of which three were female school and two of them were Grant-aided. The rest were Coeducational. The remaining seven schools were government run schools. The idea for such a choice of schools was to compare and contrast performance between Grant-aided and Government run schools, Between Government run schools, and between single sex run schools.

\subsection{Research Design}

To understand the meanings, perceptions, attitudes and ideas of the participants regarding the concept of 'equal opportunity' in the teaching and learning of geography in the Zambian Kabwe District Senior Secondary Schools, researchers adopted Case Study Design.

\subsection{Sample Size and Techniques}

201 key stakeholders who included165 (65 male and 100 female)grade 11 and 12 learners of geography, 26 (14 male and 12 female) teachers of geography, 2 head teachers, 2 heads of social sciences departments, 3 University trainers of teachers of geography and 3 Ministry of Education geography specialists were interviewed. Purposive sampling was used to pick all stakeholders. For learners, the researchers used class lists to pick the total number of the required respondents and simple lottery technique was used. A structured questionnaire was used on all stakeholders except on head teachers who were interviewed using interview guide schedule. The questionnaire and interview guide schedule were conducted to help generate new themes and ideas about the teaching and learning 
of geography for 'equal opportunity'. Learner participants were provided with informed consent forms to explain what the study was about, their level of participation and also to guarantee them confidentially. Triangulation was done by comparing different kinds of data from different instruments to confirm whether they collaborated (Cohen et al., 2000). To enhance reliability of the findings, the data collected in this study, were verified by using triangulation and respondent validation. In this study, validity, therefore, was the degree to which the findings accurately and appropriately represented the participants' experiences, beliefs, opinions and attitudes as regards 'equal opportunity' in senior secondary schools' geography of Kabwe District. Due to ethical considerations, the sampled Secondary Schools were represented by pseudo names.

\subsection{Data Analysis}

Interview schedules, classroom observations, reviewed documents and questionnaires, were analysed using generated themes and document analysis approach.

\section{ReSUlts}

\subsection{Causes of Underachievement in the teaching and learning of Geography in Kabwe District Senior Secondary Schools}

Research question sought to establish the causes of underachievement in the teaching and learning of geography for 'equal opportunity' in Zambian Kabwe Senior Secondary Schools. Table 1 displays the findings concerning the causes of underachievement in the teaching and learning of geography for 'equal opportunity' in Zambian Kabwe senior secondary schools.

Table1: Causes of Underachievement in Selected Kabwe District Senior Secondary Schools

\begin{tabular}{|c|c|c|}
\hline Internal Causes & External Causes & Other Causes \\
\hline $\begin{array}{ll}\text { - } & \text { Poverty } \\
\text { - } & \text { Education attainment of } \\
\text { parents } \\
\text { - } & \text { Economic status of parents }\end{array}$ & $\begin{array}{ll}\text { - } & \text { Selective teacher-learner } \\
\text { interaction } \\
\text { - } & \text { Non -availability of teaching and } \\
& \text { learning resources } \\
\text { - } & \text { Disparity in teacher qualification } \\
\text { - } & \text { High teacher - pupil ratio } \\
\text { - } & \text { Teacher and learner absenteeism }\end{array}$ & $\begin{array}{ll}\text { - } & \text { Distance between home and } \\
\text { school } \\
\text { - } \\
\text { - } \text { Gender issues } \\
\text { learners attitude towards } \\
\text { learning }\end{array}$ \\
\hline
\end{tabular}

The findings revealed three causes which were grouped into broad terms: internal causes (learner home environment); external causes (learner school environments); and other causes (learner personal challenges).

\section{DISCUSSION}

\subsection{Internal Causes}

Findings showed that poverty related factors contributed to the underachievement observed in Kabwe District Senior Secondary Schools. This was partly due to the failure by some learners to pay for field work excursions which made the affected learners to miss some lessons leading to poor performance in the geography field project and, that on average, affected their overall performance in geography. Mundende (2015) observed that there were challenges in implementing field work which included cost. The study's findings were consistent with what Haughton and Khandker (2009) and Jensen (2012); Parrett and Budge (2012) wrote that high poverty schools did not perform well academically and low achievement continued to be the way of life. From the Government of Zambia policy point of view as regards the poor and the vulnerable, it was envisaged that Education Boards would be required to adopt a policy of positive and affirmative action in relation to the poor and vulnerable whose needs they served. It was emphasised that there was no child who would be excluded from school or from any school activity on grounds of failure to pay or being unable to afford the necessary materials, school uniform or similar item; the Ministry would establish bursary and scholarship schemes targeted towards the poor and vulnerable...attending boarding schools (MoE, 1996). A follow up on these guidelines is needed because during the data collection phase of this study, some learners were not allowed to attend classes for non-payment of school fees. A typical example of what obtained in most Zambian Primary and Secondary Schools is what transpired at Kalilwe Primary School in Mumbwa where more than 600 pupils (including Grades 5, 6 and 7) 
were barred from writing their end of 2019 Term-Two tests by their school administrator for failure to pay K50 user fee contrary to the new policy (Times of Zambia Newspaper, 2019). As regards bursaries and scholarships, they were common and more pronounced in institutions of higher learning and not in secondary schools. Therefore, it was not 'equal opportunity' where some learners were deprived an opportunity to attend classes or field excursions because of their inability to pay their school bills as and when schools demanded.

Similarly, parental educational attainment was identified as another factor of 'unequal opportunities', contributing to underperformance. The researchers found out that some learners were sent by their parents or guardians to sell some merchandise to raise money for food and other expenses instead of attending classes. Other parents stopped their children (especially girl child) from attending school and gave them into marriage. To a large extent, this attitude and way of thinking could only be entertained by a parent who did not appreciate education and what it could do. The researchers's findings concerning educational attainment of parents was consistent with other works that parents who did not value education were those who did not go far in their education. But other factors were as just important, including family interest in education and family resources, which were not controlled by the school (Lieberman, 1993, and Jensen, 2012).

Another major finding from the research was that distance between home and school contributed to the unequal opportunities which led into underperformance in Kabwe District Senior Secondary Schools. Some learners lived far from their schools which made them to be weekly boarders, since among the schools under discussion, there were no boarding schools. Nonetheless, there was some great effort and deliberate policy from the government through the Ministry of General Education (MoGE) to construct schools and upgrade some to the expected standards.

\subsection{External Causes}

This current research argues that, if all schools effectively and efficiently implemented individualised learner support/teaching, 'equal opportunity', 'equality of opportunities' or/and 'equity', would be enhanced. If that happened, learners would score highly in their academic pursuit in geography as compared to what currently was being experienced in Kabwe District schools, and such would improve the general academic standing at Provincial and National levels respectively (Kryriacou, 1991; GRZ, 1996). Despite observed large classes in Kabwe District schools, teachers should endeavour to provide high level of teacher-learner interaction by providing individualised attention to learners under their charge.

Another major finding which was consistent with the works of Smith (1997; Butt and Lambert, 1996; MoE, 1996) was that inadequate resources, particularly textbooks and maps contributed to poor academic performance. Learning resources were necessary for quality education to be imparted. Adequate learning resources equalised the academic playing field where every learner had a better chance at succeeding in the learning process. It was not 'equal opportunity' if teaching and learning resources were not equitably distributed to individual teachers and learners as well as to all schools.

Concerning teacher qualifications, the study revealed that most of the teachers in Kabwe Secondary Schools had first degrees, although a few had diplomas. Majority of learners preferred teachers who had obtained at least a bachelor's degree qualification in geography. Not withstanding the importance of teachers holding degree qualification, learners also needed teachers who were inspiring and who affirmed that learners were the most important part in the nexus called education (Aydin and Aslan, 2016). The Zambian government policy guidelines state that grades 10 to 12 were to be taught by degree holders except in English and Science related subjects, but as for Kabwe District senior secondary schools, non-degreed teachers taught at senior level, contrary to the policy. This misdirection of human resources may have led to poor performance in Kabwe District at School Certificate level. It could have been substantiated to have correlation information on high scores and educational status of the teacher, but it is not the scope of this study. Even that situation may not reveal much because one may not hold a degree but acquire knowledge through Continuing Professional Development (CPD). It was therefore, not 'equal opportunities' where some learners were taught by diploma holders and others by degree holders.

With regard to the teacher-pupil ratio, the findings showed a wide range of values in the selected Kabwe Senior Secondary Schools from 1:25 at one grant-aided school to 1:75 at one government 
school. These ratios are evidence enough to deduce why perhaps grant aided performed better than government run schools. Various scholars attest to the fact that small classes offer powerful teaching opportunities for educators to do more effectively what they know right in terms of teaching and learning because learners become more engaged academically and socially when class sizes are reduced (Finn and Achilles, 1999; Finn et al., 2003). Zambian schools had high teacher-pupil ratios partly due to high enrollment levels. Comparatively, the ratios differed between rural and urban schools. The recommended teacher-pupil ratio in Zambian schools is 1:40. It was not 'equal opportunity' when disparity in teacher-pupil ratio was allowed by the Zambian education systems in Kabwe District. Hence, it was high time that teacher-pupil ratio was normalised in Zambian Schools if 'equal opportunity' was to be realised.

\subsection{Other Causes}

Regarding absenteeism among teachers and learners in Kabwe District senior secondary schools, this could have contributed to the underachievement under discussion. Some learners did not seem to value education and were simply forced to go to school by their parents or/and teachers. Some learners did not consistently attend classes and such contributed to their poor performance. Such records were evidenced by the number $(226,353)$ of learners who entered for geography but only 206 , 324 sat examination. By implication, over the period of 8 years, 20,029 candidates dropped out and did not write geography. This is consistent with Tilbury and Williams (1997) who cited personal factors as one of the main factors that affected 'equal opportunity' and such included long distances which some learners covered from their homes to schools (especially in rural settings), exorbitant fees, and levies paid at school. One head teacher said that those learners who did not perform to their set standards and from time to time were absent from school, did not proceed to the next grade. As for teachers who did not conduct themselves as expected were surrendered back to the MoGE.

\section{CONCLuSion}

The study revealed that the causes of underachievement in the teaching and learning of Geography for 'equal opportunity' in Zambian Senior Secondary Schools of Kabwe District were broadly categorised as internal, external, and other factors. Internal causes include poverty, parental educational attainment, and socio-economic status of parents. External factors include selective teacher-learner interaction, non-availability of teaching and learning resources, disparity in the teacher qualification, and unstandardised teacher-pupil ratios. Other causes include distance between home and school, gender issues, and learners' attitude toward learning.

Findings showed that the poverty related factors contributed to the underachievement observed in Senior Secondary Schools of Kabwe District. This was partly due to the failure by some learners to pay for field work excursions which made the affected learners to miss some lessons leading to poor performance in the Geography field project. This in turn, affected their overall performance in Geography. The study deduced that poverty could have been an underlying factor in the poor performance of learners in some selected schools. This finding was consistent with what Haughton and Khandker (2009); Parrett and Budge (2012) wrote that high poverty schools did not perform well academically hence low achievement continues to be the way of life. From the Zambian Government's policy point of view vis-a-vis the poor and the vulnerable, it was envisaged that Education Boards would be required to adopt a policy of positive and affirmative action in relation to the poor and vulnerable whose needs they served (MoE, 1996), yet some learners were excluded. A follow up on these guidelines was needed because during the data collection phase of the study, some learners were not allowed to attend classes for non-payment of school fees. It was not 'equal opportunity' where some learners were deprived of the opportunity to attend classes or field excursions because of their inability to pay their school bills as and when schools demanded.

Parental educational attainment was also identified as another factor of 'unequal opportunities' contributing to underperformance. Some learners were sent by their parents or guardians to sell some merchandise to raise money for food and other expenses instead of attending classes. Other parents stopped their children (especially girl child) from attending school and gave them into marriage. The researcher's findings concerning educational attainment of parents was consistent with other works that parents who did not value education were those who did not go far in their education. But other factors were just as important, including family interest in education and family resources, which were not controlled by the school (Lieberman, 1993). 
Distance between home and school contributed to the unequal opportunities which lead to underperformance in Senior Secondary Schools of Kabwe District. Some learners lived far from their schools which made some of them to be weekly boarders, since among the schools investigated, there were no boarding schools in Kabwe District. There was deliberate policy from the government through the MoGE to construct more schools and upgrade some to the expected standards.

Regarding individualised teaching, the study argues that if all schools effectively and efficiently implemented individualised learner support/teaching, 'equal opportunity', 'equality of opportunities' or/and 'equity', would be enhanced. If this happened, learners would score highly in their academic pursuit in Geography as compared to what is currently being experienced in Kabwe District schools. This would also improve the general academic standing at provincial and national levels respectively. Literature supported this finding (Kryriacou, 1991; MoE, 1996). Therefore, despite the observable large classes in the Kabwe District schools, teachers should endeavour to provide a high level of teacher-learner interaction by providing individualised attention to learners under their charge.

Another major finding which was consistent with the works of Smith (1997), Butt and Lambert, (1996) and MoE, 1996) was that inadequate resources, particularly textbooks and maps contributed to poor academic performance. Adequate learning resources equalised the academic playing field where every learner had a better chance at succeeding in the learning process. It was not 'equal opportunity' if teaching and learning resources were not equitably distributed to individual teachers and learners as well as to all schools.

Concerning teacher qualifications, the study revealed that most of the teachers in Kabwe District Secondary Schools had first degrees, although a few had diplomas. Not with-standing the importance of teachers holding degree qualifications, learners also needed teachers who were inspiring and who affirmed that learners were the most important part in the nexus called education (Aydin and Aslan, 2016). The Zambian government policy guidelines state that Grades 10 to 12 are to be taught by degree holders except in English and Science related subjects, but as for Senior Secondary Schools of Kabwe District, non-degreed teachers taught at senior secondary school, contrary to the policy. This misdirection of human resources may have led to the poor performance at the school certificate level.

With regards to the teacher-pupil ratio, the findings showed a wide range of values in the selected Kabwe senior secondary schools from 1:25 at one grant-aided school to 1:75 at one government school. These ratios were enough evidence of why perhaps the grant-aided schools performed better than the government schools. The recommended teacher-pupil ratio in Zambian schools is 1:40 but Zambian schools have high teacher-pupil ratios partly due to high enrolment levels. It is not 'equal opportunity' when disparity in teacher-pupil ratio was allowed by the Zambian education systems in Kabwe District. Absenteeism among teachers and learners was another major finding. Some learners did not seem to value education and were simply forced to go to school by their parents or/and teachers. Some learners did not consistently attend classes and this consequently contributed to their poor performance. This was attested to by the number of learners who for the period under discussion entered for Geography but did not sit for any examination.

\section{ACKNOWLEDGEMENTS}

I am greatly indebted to Professor Namafe M. Charles for being my mentor in academic writing and journey. I also thank Professor Boniface Namangala, for encouraging me to Publish or I perish. A big thank you to my wife, Precious Muleya for permitting me to concentrate on academic pursuant at the expense of being with her. I thank the Ministry of General Education, to grant me authority to carry out this study in selected Kabwe District Secondary Schools. Similarly, I corporately thank all the selected Schools in Kabwe where this study was conducted. Supremely, I thank my awesome God for preserving my health before, during and after the activities of this study.

\section{RECOMMENDATIONS}

In view of the need to improve performance in the teaching and learning of geography for 'equal opportunity' in Kabwe District senior secondary schools, this research gives the following recommendations:

- Secondary schools administrators should allocate all trained geography teachers teaching periods at senior classes level. This is based on the finding that some geography trained teachers were not allocated geography periods. 
- The Parents Teacher Association (PTA) should work closely with the School administrators to ensure that their children are obedient and attend classes.

- MoGE should deploy qualified geography teachers with same or similar qualifications to all schools. This is due to the finding that Kabwe District secondary schools had diploma, first degree and few second degree holders.

- MoGE should enforce standardised teacher-pupil ratio of 1:40. This is because of the finding that private schools had regulated ratio while public schools had unregulated teacher-pupil ratio.

- School administrators should closely monitor, and supervise individualised teacher-learner attention. This is due to the finding that most teachers taught more than one class and large classes.

- MoGE should evaluate the implementation of the 1996 Education Policy document. This is based on the findings that some 1996 Educational policies, such as who should teach at senior secondary level and provision of learning and teaching resources were ineffective.

\section{REFERENCES}

[1] Ary, D., Jacobs, C. L., Sorensen, C., and Razavieh, A., (2010). Introduction to Research in Education. Wadsworth: Belmont.

[2] Aydin, H., and Aslan, D., (2016). "Determining Attitudes towards Pedagogical Teacher Training: A Scale Development Study" inJournal of Education and Learning. 5 (3), 1.

[3] Burbules, C. N., Lord, T.P., and Sherman, L. A., (1982). "Equity, Equal Opportunity and Education" in Educational Evaluation and Policy Analysis Vol 2 (Summer, 1982) pp 169 - 187). American Educational Research Association.

[4] Cohen, L., Manion, L., and Morrison, K. (2000). Research Methods in Education. London: $5^{\text {th }}$ Edition, Routledge Falmer: London.

[5] ECZ (2013). 2013. Examinations Performance Report: Social and Business Sciences Booklet. Lusaka: ECZ.

[6] Finn, J.D., Pannozzo, G.M., and Achilles, C.M., (2003). The "Why" of Class Size: Student behavior in small classes, Review of Educational Research, 73 (3), 21- 368.

[7] MoE (1996). Educating Our Future: National Policy On Education. Lusaka: ZEPH.

[8] Guy, R. (2009). (Ed.). The Evolution of Mobile Teaching and Learning. California: Informing Science Press.

[9] Harfitt, J. G., (2015). Class Size Reduction: Key Insights from Secondary School Classrooms. Springer: New York.

[10] Hattie, J., (2005). "The Paradox of reducing class size and improving learning outcomes". International Journal of Educational Research, 43, $387-425$.

[11] Haughton, J. and Khandker, R. S. (2009). Handbook on Poverty and Inequality. Washington, DC: The World Bank.

[12] Hilda, T.A., and Bakker, N., (2014). "Comprehensive education: lost in the mi(d)st of a debate. Dutch politicians on equal opportunity in secondary schooling (1965 - 1979)" in History of Education Vol. 43, No 5, 660.

[13] Howe, B.R. and Covell, K. (2013). Education in the Best Interests of the Child: A Children's Rights Perspective on Closing the Achievement Gap. Toronto: University of Toronto Press.

[14] Jensen, E. (2009). Teaching and Poverty in Mind: What Being Poor Does to Kid's and What Schools Can do About it. ACSD: Alexandria.

[15] Johari, C.J., (2012). Contemporary Political Theory: New Dimensions, Basic Concepts and Major Trends. New Delhi: Sterling Publisher Private Limited.

[16] Kyriacou, C., (1997). Effective Teaching in Schools: Theory and Practice. Nelson Thornes.

[17] Lambert, D., and Balderstone, D., (2000). Learning to Teach Geography in the Secondary School. London and New York: Routledge Falmer.

[18] Lieberman, M. (1993). Public Education: An Autopsy. Harvard University Press: London.

[19] Leat, D., (1997). 'Cognitive acceleration in geographical education' in Tilbury, D. and Williams, M. (eds), Teaching and Learning Geography. London: Routledge.

[20] Majo, S. (2016). 'Factors Influencing Poor Performance in Science Subjects in Secondary Schools in Shinyanga Municipality'. Master's Thesis, GRIN Verlag.

[21] Mayhew, S. (2015). Oxford Dictionary of Geography. Oxford University Press: Oxford.

[22] Ministry of Education (MoE), (1996). Educating our future: National Policy on Education, Lusaka: Zambia Educational Publishing House. 
Exploring the Concept of Equal Opportunity in Teaching and Learning of Geography in Selected Secondary Schools of Kabwe District, Zambia

[23] MoESVTEE (2012). National Assessment of Learning Achievement at the Primary School Level: Zambia's National Assessment Survey Report - 2012. Lusaka.

[24] Mundende, K. (2015). "Implementation of Geography Field Project in Zambian High Schools: A Survey of Livingstone and Monze Towns of Southern Province", International Journal of Research in Geography. I, 38 - 52.

[25] Okada, A. (2012). Education Policy and Equal Opportunity in Japan. Berghahn Books: New York.

[26] OFSTED (1995). Geography. A Review of Inspection Findings 1993/4. London: TSO.

[27] Parrett, H.W. and Budge, M.K. (2012). Turning High - Poverty Schools into High - Performing Schools. St. Alexandria: ASCD.

[28] Pop, D (Ed.), (2012). Education Policy and Equal Opportunities. New York: Open Society Foundation.

[29] Rice, J.K., (1999). "The Impact of Class Size on Instructional Strategies and the Use of time in High School Mathematics and Science Courses". Educational Evaluation and Policy Analysis, 2 92), 215 - 229

[30] Smith, P., (1997). 'Standards Achieved: A Review of Geography in Secondary Schools in England 1995 96', Teaching Geography22 (3), 123 - 124.

[31] Times of Zambia (2019) "600 Mumbwa pupils miss tests over user fees”. Friday, April 12, p.1.

[32] The Post (2013). "Society must remove negative gender norms, says Chimango". Tuesday, October 29, p. 11 , issue no: 6220.

[33] The Post (2013) “Parents, Teachers are key in fighting vices - Kalomo NGO”. Tuesday October 29, p 15, issue no 6220.

[34] Tilbury, D., and Williams, M., (1997). Teaching and Learning Geography. London and New York: Routledge.

[35] Watkinson, A. (2010). The Essentials Guide for New Teaching Assistants: Assisting Learning and Supporting Teaching in the Classroom. Second Edition; A David Fulton Book.

[36] Wills, W.J. and Jost. M. (2007). Foundations of Qualitative Research: Interpretive and Critical Approaches. London: SAGE Publications.

[37] Woessmann, L. and Peterson, E. P. (2007). Schools and the Education Opportunity Problem. Cambridge: The MIT Press.

[38] World Bank - Education Data (2018). https://www.globalpartnership.org/country/zambia (last updated, October 17, 2018.

\section{AUTHORS' BIOGRAPHY}

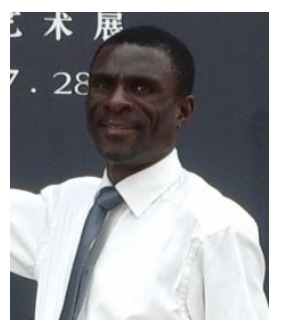

Kasonde Mundende (Mr.) is a Lecturer of Geography at the University of Zambia, Lusaka, Zambia. Currently he teaches three courses, namely: Migration, Refugees and Environment; Population, Culture and Environment and Fundamental Topics in Secondary School Geography. He is attached to the Institute of Distance Education (IDE) of the University of Zambia (UNZA) currently serving as the Head of Department of Learner Support Services. His passion is in Geography Education, Distance Education/Learning and Instructional design and technology. He has the following qualifications: Primary Teachers' Certificate, Secondary Teacher Diploma (Single Major Mathematics), Bachelor of Arts with Education (B.A. Ed) (Single Major Geography) and Master of Education (M. Ed) - Geography Education. Additionally, he possesses a Certificate for Distance Education Practitioners (CDEP) from Botswana College of Distance and Open Learning (BOCODOL). Currently, he is pursuing Master of Instructional Design and Technology with Malaysia Open University and Philosophy of Doctorate $(\mathrm{PhD})$ in Geography Education.

Charles M. Namafe is an Associate Professor of Geography /Environmental Education, in the School of Education at the University of Zambia, Lusaka, Zambia.

Citation: Kasonde Mundende, et.al. "Exploring the Concept of Equal Opportunity in Teaching and Learning of Geography in Selected Secondary Schools of Kabwe District, Zambia”. International Journal of Research in Geography. vol 5, no. 4, 2019, pp. 23-33 doi: http://dx.doi. org/10.20431/2454-8685.0504003.

Copyright: (C) 2019 Authors. This is an open-access article distributed under the terms of the Creative Commons Attribution License, which permits unrestricted use, distribution, and reproduction in any medium, provided the original author and source are credited. 